\title{
Pengasuhan Otoritatif, Dukungan Teman Sebaya dan Regulasi Emosi Dengan Perilaku Prososial Remaja di Media Sosial
}

\author{
Nur Indah Sari,Yudhi Satria Restu \\ Universitas Muhammadiyah Surakarta \\ email: indah.xiipms1@gmail
}

\begin{abstract}
Abstrak
Artikel INFO

Diterima:30 Okt 2019

Direvisi :28 Jan 2020

Disetujui: 05 Mei 2020

DOI:

http://dx.doi.org/10.24014/

jp.v14i2.8168

Perilaku prososial di media sosial merupakan fenomena terjadinya perilaku untuk saling menolong sesama dalam dunia internet. Hal tersebut perlu dijadikan referensi bagi dunia pendidikan karena perilaku prososial di media sosial dapat mendukung perkembangan sosial pada remaja. Penelitian ini bertujuan untuk mengkaji pengasuhan otoritatif orang tua, dukungan teman sebaya, dan regulasi emosi dengan kecenderungan perilaku prososial di media sosial oleh remaja. Teknik pengambilan sampel dalam penelitian ini adalah purposive sampling, dengan sampel penelitian sebanyak 334 remaja. Pengumpulan data dengan menggunakan skala pengasuhan otoritatif orang tua, skala dukungan teman sebaya, skala regulasi emosi, dan skala perilaku prososial di media sosial. Data dianalisis menggunakan metode Structural Equation Modeling (SEM) dengan aplikasi Lisrel versi 8.7. Berdasarkan hasil pengujian SEM diketahui bahwa pengasuhan otoritatif orang tua, dukungan teman sebaya, dan regulasi emosi memiliki hubungan langsung terhadap perilaku prososial di media sosial. Selain itu, hasil analisis data menunjukkan bahwa regulasi emosi terbukti mampu sebagai mediasi pada hubungan antara pengasuhan otoritatif orang tua dengan perilaku prososial di media sosial. Penelitian ini berimplikasi untuk umpan balik terhadap perilaku prososial di berbagai media sosial.
\end{abstract}

Kata-kata kunci: Pengasuhan Otoritatif, Dukungan Teman Sebaya, Regulasi Emosi, Perilaku Prososial.

\section{Authoritative Parenting, Peer Support and Emotion Regulation on The Prosocial Behavior Tendencies Adolescents in Social Media}

\begin{abstract}
Prosocial behavior on social media is a phenomenon which is discussed to help one another in the internet world. It needs to be used as a reference in the world of education because it can support social development in adolescents. The purpose of the study was to investigate the authorative parenting, peer support and emotion regulation on the prosocial behavior tendencies in social media of adolescents. The sampling technique in this study was purposive sampling, with a sample of 334 adolescents. The data collections were obtained by using authorative parenting scale, peer support scale, emotion regulation scale, and prosocial behavior tendencies scale. The data were analyzed by using the Structural Equation Modeling (SEM) method with Lisrel version 8.7. Based on the results of testing SEM it showed that authorative parenting, peer support, and emotion regulation had a direct effect to prosocial behavior tendencies in social media. Furthermore, the results of data analysis showed that emotion regulation was proven to be able as a mediator in the correlation authorative parenting with prosocial behavior tendencies in social media. This research has implications as material for feedback on prosocial behavior tendencies in social media.
\end{abstract}

Keywords: Authoritative Parenting, Peer Support, Emotion Regulation, Prosocial Behavior.

\section{Pendahuluan}

Media sosial merupakan salah satu alat komunikasi yang paling banyak digunakan pengguna internet di seluruh belahan dunia untuk menyebarkan atau berbagi informasi yang spesifik dan juga bermanfaat, seperti: gaya hidup, teknologi, bisnis, motivasi, kesehatan maupun kegiatan sosial. Informasi yang memberitahukan tentang kegiatan sosial 
seperti kegiatan donor darah, sumbangan bencana alam dan peduli lingkungan hidup merupakan informasi yang intensitasnya tinggi dan sering di bagikan ulang oleh pengguna media sosial (Luthfie, 2011). Hal ini menunjukkan bahwa media sosial dapat berfungsi dalam menggerakkan penggunanya untuk melakukan kegiatan sosial yang bermanfaat bagi pengguna lainnya.

Salah satu bentuk gerakan sosial di media sosial dapat dilihat dari Bencana Alam Gempa dan Tsunami yang terjadi beberapa saat belakangan ini, menjadi salah satu bukti nyata bahwa media sosial contohnya Instagram dapat menggerakkan penggunanya untuk melakukan hal yang bermanfaat bagi orang lain. Banyak akun-akun yang menyebarkan informasi maupun berbagi ulang informasi atau repost mengenai kegiatan sosial dalam rangka membantu para korban bencana gempa dan tsunami. Salah satunya akun instagram @tatjanasaphira yang berbagi ulang atau repost informasi donasi untuk Bencana Alam yang terjadi pada bulan September 2018 dari akun @kitabisacom @actforhumanity : Bersama Yayasan Aksi Cepat Tanggap, aku ingin mengajak temanteman untuk membantu saudara-saudara di sana dengan cara berdonasi melalui https:// www.kitabisa.com. Postingan ini mendapatkan respon 72 komentar 21.663 hingga dalam laman kitabisa.com/tatjanauntukdonggala terkumpul donasi sebesar Rp22 juta. Selain itu, masih banyak informasi mengenai kegiatan sosial yang dibagikan melalui jejaring sosal Twitter. Namun, pada kenyataannya tidak semua pengguna media sosial mengambil keputusan untuk berbagi ulang informasi mengenai kegiatan sosial yang memiliki tujuan dan manfaat bagi orang lain maupun lingkungannya. Hal ini dipengaruhi oleh situasi atau lingkungan yang menjadikan individu hidup dengan lebih individualis atau cenderung bersikap mementingkan dirinya sendiri. Dengan banyaknya aktivitas dan juga adanya perkembangan teknologi yang semakin canggih, menjadikan seseorang cenderung lebih fokus pada diri sendiri dan kurang memberikan perhatian terhadap lingkungan sosial sekitarnya.
Afrianti \& Anggraeni (2016) mengemukakan bahwa remaja yang memperlihatkan perilaku prososial mengindikasikan perkembangan psikososial yang sehat. Namun, masalahnya saat ini lebih banyak menunjukkan kurangnya perilaku prososial remaja terlihat seperti pada peristiwa gempa yang terjadi di Palu dan Donggala bulan September 2018 kemarin. Peristiwa tersebut menimbulkan banyak korban jiwa dan menghancurkan sarana serta prasana daerah, salah satu grub komunitas di LINE pada mahasiswa $X$ yang mengatakan saat dirinya membagikan informasi di grub bahwa ada seseorang yang sedang membutuhkan bantuan karena kondisi yang darurat, dari 376 yang tercatat sebagai anggota tidak lebih dari 25 orang yang memberikan respon dan keseriusan dalam menanggapi informasi yang disampaikan, lebih dari $50 \%$ anggota hanya membaca tanpa menanggapi (silent reader), dan lainnya bahkan belum melihat sehingga informasi tersebut sampai akhirnya berlalu begitu saja. Kepedulian rendah yang dimiliki remaja menunjukkan bahwa mereka cenderung kurang memahami kondisi orang lain, padahal dengan rasa peduli seseorang bisa memberikan bantuan atau pertolongan, tetapi hal tersebut tidak terjadi. Hal tersebut menunjukkan bahwa remaja cenderung kurang memiliki perilaku prososial saat berhubungan melalui media sosial.

Remaja yang cenderung lebih menunjukkan perilaku prososial lebih terhindar dari teman yang sering memilih masalah perilaku berisiko dan kenakalan remaja, mereka tidak ingin terlibat dengan tindakan yang merugikan diri sendiri dan menyakiti orang lain, misal melakukan tindakan agresivitas (Carlo, Mestre, McGinley, Porcar, Samper, \& Opal, 2014; De Caroli \& Sagonea , 2014). Perilaku prososial juga memiliki pengaruh pada kesejahteraan seseorang, ketika seseorang memberikan bantuan kepada orang lain atau menjadi relawan muncul kebahagiaan yang menjadi salah satu tolak ukur kesejahteraan (Kahana, Bhatta, Lovegreen, Kahan, \& Midlarsky, 2013; Lam, 2013). Selain itu remaja yang memiliki perilaku prososial menunjukkan perkembangan psikososial 
yang sehat (Steinberg, 2011).

Wujud nyata dari rendahnya prososial di media sosial dapat dilihat juga dari fenomena yang terjadi seperti berita fenomena sosial maraknya selfie di dekat korban kecelakaan atau bencana alam. Sindonews.com dikabarkan bahwa seorang pria yang malah asyik mengambil foto selfie dan memvideokan tiga korban kecelakaan yang tengah sekarat alih-alih untuk membantunya. Sebuah video yang diunggah ke media sosial menunjukkan belasan pria berdiri melingkar menonton para korban yang menggeliat kesakitan dan memohon bantuan. Para korban akhirnya meninggal karena kehabisan darah. Polisi setempat mengatakan tidak ada seorang pun berusaha memberikan pertolongan pertama atau membawa para korban ke rumah sakit seperti dikutip dari $A B C$.net.au, Kamis (12/07/2018). Sebagaimana yang dijelaskan oleh Johnston \& Kretteaneur (2011) bahwa remaja yang cenderung tidak memperdulikan norma, dan merasa tidak bersalah ketika dirinya telah merugikan orang lain secara fisik maupun psikis, yang artinya perilaku mereka cenderung mengarahkan pada antisosial.

Sebaliknya ketika seseorang memiliki perilaku prososial yang tinggi, maka mereka tidak akan mengunggah ke media sosial kejadian tersebut. Namun, yang akan mereka unggah adalah ajakan untuk memberi donasi, kegiatan bersih-bersih lingkungan, dan lainnya agar orang lain juga ikut berkontribusi melakukan hal yang positif. Hal tersebut didukung oleh Faturochman (2006) mengartikan perilaku prososial sebagai perilaku yang memberi konsekuensi positif pada orang lain. Perilaku prososial pada umumnya diperoleh melalui proses belajar.

Proses belajar dalam social learning theory percaya perilaku dipelajari dari proses observasi melalui model (Bandura, 1977). Dalam social learning theory mempelajari tingkah laku prososial yaitu prinsip modeling dan reinforcement. Dikatakan perilaku prososial baik yaitu ketika terjadi tindakan menolong yang menguntungkan orang lain tanpa harus menyediakan suatu keuntungan langsung pada orang yang melakukan tindakan tersebut, dan bahkan melibatkan suatu resiko bagi orang yang menolong (Baron dan Byrne, 2005).

Adapun manfaat dari penelitian ini memberikan informasi akan pentingnya pengasuhan otoritatif orang tua, dukungan teman sebaya dan regulasi emosi yang mempengaruhi perilaku prososial di media sosial pada remaja, sehingga dapat menjadi bahan pengetahuan bagi para pelajar dan orang tua terkait perilaku prososial di media sosial yang bisa memberikan dampak yang lebih positif. Kajian tentang perilaku prososial telah banyak dilakukan oleh peneliti lain salah satunya oleh Erreygers, Vandebosch, Vranjes, Baillien, \& De Witte (2017) dan Ferenczi N., Marshall, T.C., Bejanyan, K (2017) yang menyatakan bahwa kecenderungan perilaku prososial tidak hanya bisa ditemui secara langsung atau face-to-face. Penelitian oleh Wright dan Li (2011); Bosancianu, Powell, dan Bratovic (2013) menjelaskan bahwa di media sosial seseorang bisa melakukan tindakan prososial seperti di dunia nyata, seperti berbagi informasi dan memberi dukungan melalui obrolan pribadi atau berkomentar di kolom status.

Perilaku prososial tidak terlepas dari peran emosi, regulasi emosi memiliki peran sebagai proses penganturan dan pengendalian emosi negatif dan positif, dan regulasi emosi dikatakan sebagai salah satu faktor internal yang mampu mempengaruhiperilaku prososial sebab melalui strategi modulasi emosi seseorang bisa meningkatkan emosi positif, sebagaimana yang dikemukakan Eisenberg, N., Fabes, R.A., \& Spinrad, T.L (2006) bahwa peran emosi sangat penting dalam perkembangan perilaku prososial. Adapun peran emosi yang merupakan motif terjadinya perilaku prososial seseorang yang melibatkan emosinya akan mempertimbangkan dan menilai untuk melakukan tindakan prososial atau tidak (Einseberg et al., 2006).

Proses regulasi emosi diawali dengan adanya pemilihan situasi yang menimbulkan emosi, seseorang memiliki pilihan untuk menghindar atau terlibat (Gross, 2014), misalnya ketika seseorang remaja dihadapkan dengan pilihan membantu atau tidak memberi bantuan pada teman yang dinilai sangat 
menyebalkan. Setelah pemilihan situasi kemudian dimodifikasi situasi sehingga bisa mengubah dampak emosi yang ditimbulkan. Mengubah emosi membutuhkan perhatian, sehingga seseorang bisa mengubah emosi dengan penilaian ulang atau mengubah cara berpikir tentang situasi, misalnya ketika memilih untuk memberi bantuan pada teman menyebalkan, si A berusaha memikirkan sikap baik yang dimiliki si B sehingga yang muncul adalah emosi positif. Selain itu, meregulasi emosi bisa dengan menekan atau menahan ekspresi emosi (Gross, 2014). Pada kesimpulannya meregulasi emosi positif bisa memunculkan emosi positif yang menimbulkan perilaku positif, seperti halnya pada perilaku prososial.

Hein et al. (2016) menjelaskan seseorang yang mampu mengatur emosinya dengan baik cenderung lebih rendah untuk mengekspresikan emosi negatif, dan kemampuan meregulasi emosi tersebut berpengaruh pada meningkatnya empati dan perilaku prososial. Sebelumnya telah dijelaskan oleh Kanacri et al. (2012) bahwa berhubungan dengan tingkat prososial di usia remaja, yang artinya proses regulasi emosi memiliki potensi berperan penting dalam perkembangan prososial khususnya selama usia remaja.

Perilaku prososial tidak hanya dipengaruhi oleh faktor internal seperti regulasi emosi yang telah disebutkan sebelumnya. Pengaruh keluarga dalam pengasuhan memiliki peran yang krusial selama masa perkembangan terutama saat diusia remaja. Altay \& Gure (2012) orang tua yang mengasuh anaknya menggunakan gaya pengasuhan otoritatif menunjukkan lebih prososial dibandingkan dengan orang tua yang menerapkan gaya pengasuhan permesif. Yoo \& Day (2013) Orang tua yang menerapkan hubungan seimbang dengan anak mempengaruhi perilaku prososial. Hubungan antar dua orang saat berkomunikasi yang ada hanya harmonisasi, orang tua menerapkan hukum saling memberi, dan mengajak anak untuk saling berdiskusi.
Remaja yang orang tuanya cenderung menerapkan pengasuhan otoritatif menunjukkan pribadi yang bertanggung jawab dan memiliki keahlian sosial yang lebih baik seperti berperilaku prososial (Steinberg, 2011; Santrock, 2014). Seperti yang dungkap dalam hasil penelitian milik Padilla-Walker et al. (2012), pengasuhan otoritatif seperti memberi dukungan dan mengizinkan kemandirian (autonomy granting) yang diterapkan orang tua pada remaja menunjukkan mereka lebih sering dalam hasil disertasinya bahwa pengasuhan otoritatif merupakan prediktor yang memilih pengaruh tinggi terhadap perilaku prososial remaja.

Orang tua yang memperhatikan kebutuhan remaja untuk otonom, memberikan kesempatan remaja untuk mengambil keputusan terkait masa depan dan mendukung dirinya untuk otonom mereka lebih mendapatkan kepuasan, dan kepuasan tersebut berhubungan dengan keterlibatan dalam perilaku prososial (Gagne, 2003). Di sisi yang lain ditemukan bahwa keluarga yang negatif dan penuh suasana ketegangan akan melemahkan kemampuan regulasi emosi pada anak (Eisenberg et al., 2001). Penelitian yang dilakukan oleh Waldinger \& Schulz (2016) mendapatkan hasil bahwa perilaku prososial dipengaruhi oleh regulasi emosi. Interaksi sosial yang luas pada masa kanak-kanak akan berpengaruh terhadap kesejahteraan pada masa dewasa. Dowell, Mina Kim, Robin O'Neil and Ross D (2002) menyatakan bahwa perilaku kedua orang tua berhubungan dengan kemampuan regulasi emosi dan kompetensi sosial yang juga termasuk perilaku prososial pada anak. Dan dukungan teman sebaya juga mempengaruhi perilaku prosisal indvidu, dimana semakin tinggi dukungan teman sebaya maka semakin tinggi juga perilaku prososial remaja (Salomon, 2004). Dari uraian diatas dapat digambarkan hubungan pengasuhan otoritatif orang tua melalui regulasi emosi dan hubungan langsung dukungan teman sebaya dengan perilaku prososial di media sosial pada remaja pada gambar berikut ini: 


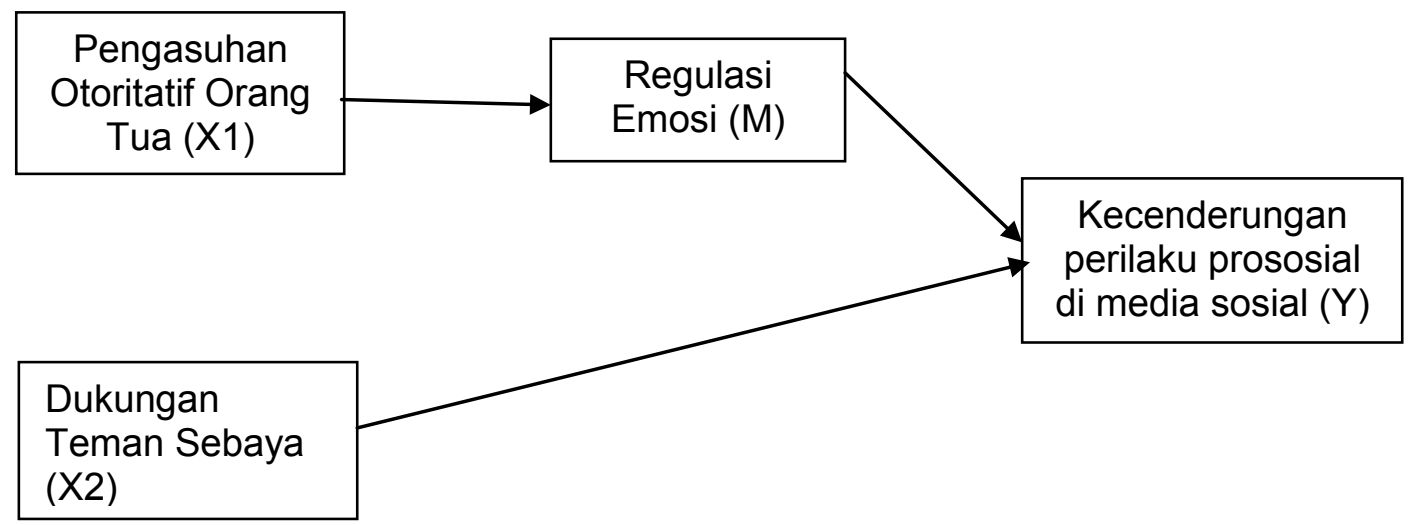

Gambar 1. Model Kerangka Teoritis

Penelitian ini ingin menguji hipotesis, yaitu: ada hubungan antara pengasuhan otoritatif orang tua melalui regulasi emosi dan hubungan langsung dukungan teman sebaya dengan kecenderungan perilaku prososial remaja di media sosial.

\section{Metode}

Populasi dan Sampel

Populasi dalam penelitian ini adalah remaja di Kota Surakarta pada Kecamatan Banjarsari berusia 14-19 tahun dengan sampel penelitian yaitu siswa SMA Negeri 1 Surakarta dan SMA Negeri 5 Surakarta dengan jumlah kuesioner yang tersebar sebanyak 500 secara purposive sampling. Dari jumlah kuesioner yang tersebar hanya 334 partisipan yang masuk kedalam kriteria subjek penelitian. Adapun kriteria subjek penelitian adalah: pertama sering menggunakan media social seperti Instagram, WhatsApp, Youtube, Facebook, LINE dan Twitter. Kedua menggunakan media social 5 jam atau lebih dalam seminggu. Ketiga tinggal bersama dengan orang tua. Adapun karakteristik partisipan dalam penelitian ini mencakup sebagai berikut:

Tabel 1.Demografi Partisipan Penelitian

\begin{tabular}{|c|c|c|c|c|}
\hline No. & Karakteristik & Kategori & Frekuensi & $\%$ \\
\hline \multirow{2}{*}{1.} & \multirow{2}{*}{ Usia } & 14-16 Tahun & 227 & $68 \%$ \\
\hline & & 17-19 Tahun & 107 & $32 \%$ \\
\hline \multirow{2}{*}{2.} & \multirow{2}{*}{ Jenis Kelamin } & Laki-Laki & 122 & $37 \%$ \\
\hline & & Perempuan & 212 & $63 \%$ \\
\hline \multirow{2}{*}{3.} & \multirow{2}{*}{ Sekolah } & SMAN 1 Surakarta & 176 & $53 \%$ \\
\hline & & SMAN 5 Surakarta & 158 & $47 \%$ \\
\hline \multirow{2}{*}{4.} & \multirow{2}{*}{ Penggunaan Media sosial } & Ya & 100 & $100 \%$ \\
\hline & & Tidak & 0 & $0 \%$ \\
\hline \multirow{2}{*}{5.} & \multirow{2}{*}{ Tinggal bersama orang tua } & Ya & 100 & $100 \%$ \\
\hline & & Tidak & 0 & $0 \%$ \\
\hline \multirow{3}{*}{6.} & \multirow{3}{*}{$\begin{array}{l}\text { Durasi Menggunakan Media } \\
\text { Sosial }\end{array}$} & 5-8 jam per minggu & 55 & $16 \%$ \\
\hline & & $9-12$ jam per minggu & 73 & $22 \%$ \\
\hline & & >12 jam per minggu & 206 & $62 \%$ \\
\hline
\end{tabular}


Berdasarkan pada Tabel 1. diatas dapat diketahui bahwa presentase partisipan yang berusia 14 sampai 16 tahun berjumlah 68\% partisipan lebih banyak dari partisipan yang berusia 17-19 tahun dengan presentase 32\% partisipan. Partisipan yang berjenis kelamin laki-laki berjumlah $37 \%$ lebih sedikit dari jumlah partisipan perempuan sebanyak $63 \%$. Dengan di dominasi partisipan yang berasal dari sekolah SMAN 1 Surakarta berjumlah $53 \%$ sedangkan SMAN 5 Surakarta berjumlah $47 \%$. Seluruh partisipan yang memenuhi kriteria sampel $100 \%$ menggunakan media sosial dan tinggal bersama dengan orang tua. Dengan durasi menggunakan media sosial yang berbeda-beda dari 5-8 jam per minggu sebesar 16\%, 9-12 jam per minggu sebesar $22 \%$, dan $>12$ jam per minggu sebesar $62 \%$. Hal ini karena partisipan yang di data dalam tabel diatas merupakan partisipan penelitian yang memenuhi kriteria sesuai variabel penelitian dalam kuesioner yang disebar.

\section{Pengukuran}

Penelitian ini menggunakan pendekatan kuantitatif, cara pengumpulan data menggunakan skala penelitian psikologi. Penelitian ini menggunakan empat jenis skala, yaitu skala skala pengasuhan otoritatif orang tua, skala dukungan teman sebaya, skala regulasi emosi, dan skala kecenderungan perilaku prososial di media sosial. Dalam penggumpulan data, peneliti dibantu oleh Kepala Bagian Hubungan Masyarakat SMA Negeri 1 Surakarta dan Guru Bimbingan Konseling SMA Negeri 5 Surakarta.

Teknik pengambilan sampel dilakukan menggunakan teknik purposive sampling yaitu teknik pengambilan sampel dengan mempertimbangkan ketentuan-ketentuan yang ada (Sugiyono, 2014). Peneliti menggunakan purposive sampling dikarenakan luasnya keseluruhan populasi dan keterbatasan yang dimiliki oleh peneliti, maka partisipan penelitian yang dipilih adalah sebagian dari keseluruhan populasi yang dinamakan sampel (Sugiyono, 2014). Selain itu, peneliti menggunakan purposive sampling dikarenakan adanya keterbatasan data mengenai pengguna media sosial yang tinggal bersama dengan orang tua tidak diketahui secara pasti di mana keberadaan partisipan tersebut. Ada tiga kriteria sampel dalam penelitian yakni : (1) partisipan penelitian merupakan pengguna aktif media sosial LINE/Instagram/Whatsapp/Facebook/Twitter, (2) partisipan penelitian menggunakan media sosial selama enam jam atau lebih dalam seminggu, (3) partisipan penelitian tinggal bersama orang tua.

Penelitian ini menggunakan empat jenis skala, yaitu skala pengasuhan otoritatif orang tua, skala dukungan teman sebaya, skala regulasi emosi dan skala kecenderungan perilaku prososial di media sosial. Dalam penggumpulan data, peneliti dibantu oleh Kepala Bagian Hubungan Masyarakat SMA Negeri 1 Surakarta dan Guru Bimbingan Konseling SMA Negeri 5 Surakarta.

Pernyataan-pernyataan dalam skala terdiri dari pernyatan favorable yaitu mendukung atau memihak pada objek sikap dan pernyataan unfavorable yaitu tidak mendukung objek sikap (Azwar, 2014). Skala menggunakan model likert dengan empat alternative jawaban yaitu sangat tidak sesuai (STS), tidak sesuai (TS), sesuai (S), dan sangat sesuai (SS). Penentuan skor pernyataan favorable untuk pilihan sangat sesuai (SS) mendapat skor 4, sesuai (S) mendapat skor 3, tidak sesuai (TS) mendapat skor 2, dan sangat tidak sesuai (STS) mendapat skor 1. Pernyataan unfavorable pilihan sangat tidak sesuai (STS) diberi skor 4 , tidak sesuai (TS) diberi skor 3 , sesuai (S) diberi skor 2, dan sangat sesuai (SS) diberi skor 1.

Salah satu contoh skala regulasi emosi yang digunakan dalam penelitian ini di mengacu pada teori regulasi emosi dari John \& Gross (2004), yang terdiri dari dua aspek yakni cognitive reappraisal dan expressive reappraisal sebagai berikut : 
Tabel 2..Blue Print Skala Regulasi Emosi

\begin{tabular}{|c|c|c|c|c|}
\hline \multirow{2}{*}{ No } & \multirow{2}{*}{ Aspek } & \multirow{2}{*}{ Indikator } & \multicolumn{2}{|c|}{ Nomor Aitem } \\
\hline & & & Favorable & Unfavorable \\
\hline 1. & $\begin{array}{l}\text { Cognitive } \\
\text { reappraisal }\end{array}$ & $\begin{array}{l}\text { - } \quad \text { Mengubah cara berpikir untuk } \\
\text { mengurangi emosi negatif } \\
\text { Mengubah apa yang dipikirkan } \\
\text { untuk mengurangi emosi negatif } \\
\text { Berpikir tentang hal yang } \\
\text { menyenangkan ketika } \\
\text { dihadapakan dengan kondisi } \\
\text { stress. }\end{array}$ & $\begin{array}{c}1,3,5,6,8,17 \\
19,21,29,31 \\
33\end{array}$ & $\begin{array}{l}2,4,7,9,10 \\
18,20,22,30 \\
32,34\end{array}$ \\
\hline 2. & $\begin{array}{l}\text { Expressive } \\
\text { suppression }\end{array}$ & $\begin{array}{l}\text { - } \quad \text { Menahan ekspresi emosi positif } \\
\text { Menahan ekspresi emosi } \\
\text { negative }\end{array}$ & $\begin{array}{c}12,14,15,23 \\
25,27\end{array}$ & $\begin{array}{c}11,13,16,24 \\
26,28\end{array}$ \\
\hline \multicolumn{3}{|c|}{ Total } & \multicolumn{2}{|c|}{34} \\
\hline
\end{tabular}

Berdasarkan hasil pengujian model pengukuran (Measurement Model) dalam menganalisa tingkat kevalidtan dan kehandalan menggunakan analisis confirmatory factor analysis method (Hair et al., 2010). Pada uji model pengukuran uji validitas konstruk dengan model pengukuran Confirmatory Factor Analysis (CFA). Validitas setiap indikator dalam pengukuran variabel latennya dapat diidentifikasi dari koefisien bobot faktor (factor loadings). Karena tekniknya adalah confirmatory maka SEM dapat mengembangkan model dengan indikator sebagai pengukur. Dikatakan valid jika masing-masing memperoleh nilai factor loading diatas $\geq 0,40$ (Ferdinand, 2000), sehingga untuk manifest (indikator) yang tidak valid pada masing-masing komponen direduksi (didrop/dibuang). Hasil Uji CFA pada masing-masing variabel dapat dijelaskan sebagai berikut :

Tabel 3.Hasil Uji Validitas dan Reliabilitas

\begin{tabular}{lccccc}
\hline \multicolumn{1}{c}{ Skala } & Jumlah Aitem & $\mathbf{2 0 . 4 0}$ & $<\mathbf{0 . 4 0}$ & CR & AVE \\
\hline Pengasuhan Otoritatif & 38 & 27 & 11 & 0.93 & 0.33 \\
Dukungan Teman & 40 & 21 & 19 & 0.88 & 0.26 \\
Regulasi Emosi & 34 & 13 & 21 & 0.79 & 0.22 \\
Perilaku Prososial & 30 & 20 & 10 & 0.90 & 0.33 \\
\hline
\end{tabular}

Berdasarkan tabel 3 diketahui bahwa semua variabel memperoleh nilai $\mathrm{CR}$ diatas 0,70 . Hal ini sesuai dengan nilai ambang batas yang digunakan untuk mengukur tingkat reliabilitas yang dapat diterima yaitu $>0,70$, sehingga masing-masing indikator variabel memiliki konsistensi internal yang baik dalam penelitian ini. Selain itu, hasil perhitungan AVE dari keempat variabel lebih kecil dari cut-offvalue yaitu 0,50 . Hair et.al (2010) mengemukakan bahwa nilai variance extraced adalah optional atau tidak diharuskan, sehingga peneliti melihat dari nilai CR sebagai ukuran reliabilitas. maka hal tersebut mengindikasikan, instrumen pengukuran reliabel dalam mengukur konstruk yang diteliti.

\section{Analisis Data}

Desain penelitian yang digunakan adalah korelasional dengan menggunakan model SEM (Structural Equation Modelling) melalui software Lisrel versi 8.7. Dalam penelitian ini SEM dibangun dari suatu model hipotesis yang terdiri dari model pengukuran dan model struktural dalam bentuk diagram jalur yang berdasarkan justifikasi teori.

\section{Hasil}

Hasil Pengujian Model Struktural (Structural Model)

Analisis selanjutnya adalah analisis Structural Equation Model (SEM) secara Full Model yang dimaksudkan untuk menguji model dan hipotesis yang dikembangkan dalam penelitian ini. Adapun hasil pengujian sebagai berikut: 


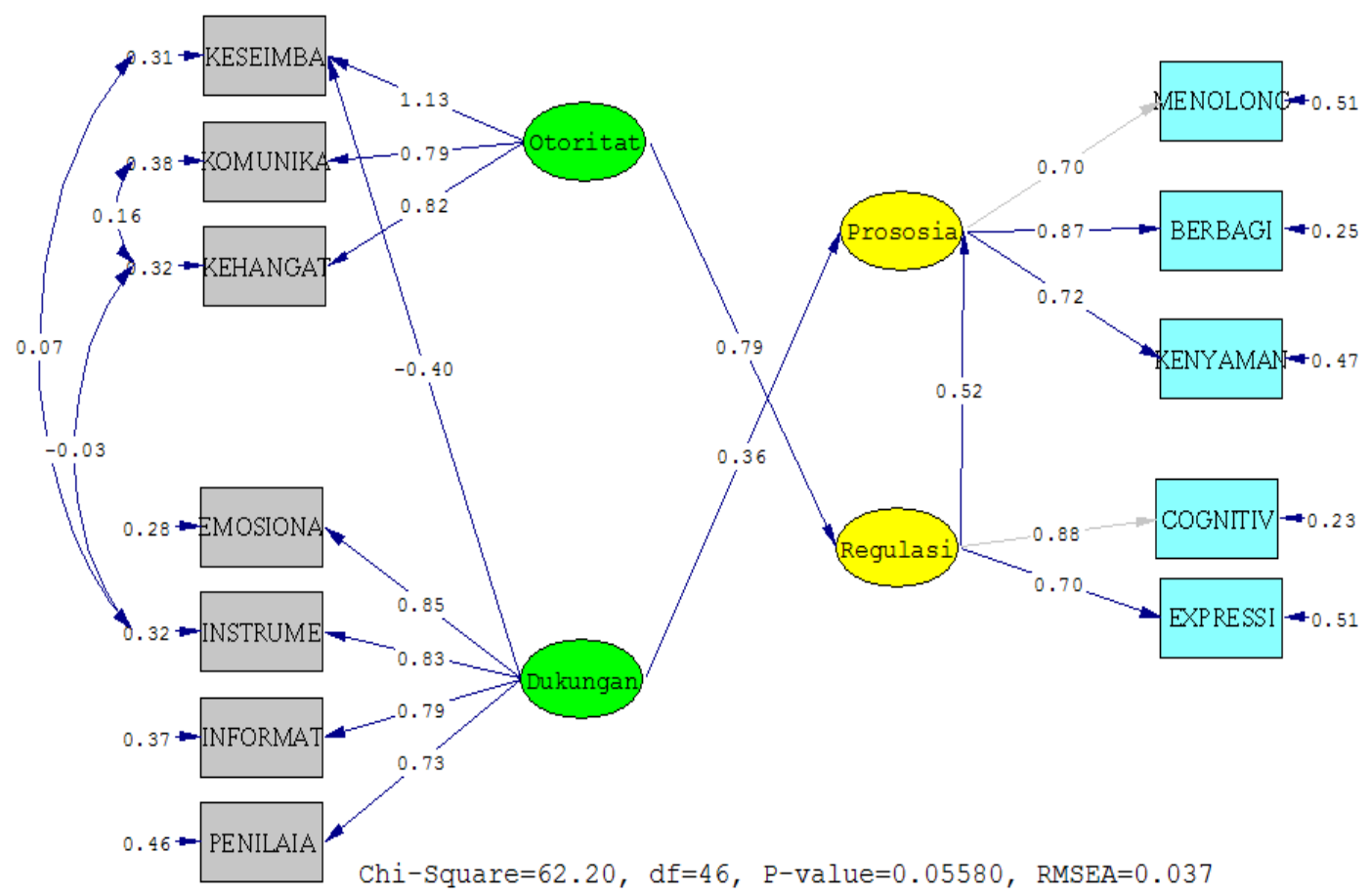

Gambar 2 Hubungan Antar Konstruk Variabel

Tabel 4. Hasil Evaluasi Goodness of fit Indices Full Model Struktural

\begin{tabular}{llll}
\hline Goodness of fit index & Kriteria & Cut of value & Keterangan \\
\hline Absolut Fit Measure & & & \\
\hline \multirow{3}{*}{ Chi-square } & Harus kecil & 62.20 & Tidak Fit \\
Significant Probability & $\geq 0,05$ & 0.056 & Fit \\
RMSEA & $\geq 0,08$ & 0.037 & Fit \\
GFI & $\geq 0,50$ & 0.960 & Fit \\
RMR & Nilai harus $\leq$ ECVI & 0.170 & Fit \\
ECVI & Independent Model & $($ IM: 16.39 dan SM: & Fit untuk direplikasi ke \\
& dan saturated model & $0.62)$ & \\
Incremental Fit Measuren selanjutnya & \\
NFI & & & \\
AGFI & $\geq 0,90$ & 0.980 & Fit \\
IFI & $\geq 0,90$ & 0.930 & Fit \\
CFI & $\geq 0,90$ & 1.000 & Fit \\
Parsimonious Goodness & Of Fit & 1.000 & Fit \\
PGFI & PGFI <GFI & 0.570 & Fit \\
PNFI & PNFI <NFI & 0.690 & Fit \\
AIC & Nilai harus $\leq$ AIC & 126.20 & Fit untuk direplikasi ke \\
& Independent Model & $(\mathrm{IM}: 4112.75$ dan SM: & penelitian selanjutnya \\
& dan saturated model & $156.00)$ & \\
& & 271.14 (IM: 4167.10 & Fit untuk direplikasi ke \\
& Nilai harus $\leq$ CAIC & dan SM: 509.30$)$ & penelitian selanjutnya \\
CAIC & Independent Model & & Fit \\
& dan saturated model & & \\
\hline
\end{tabular}


Berdasarkan dari hasil analisa prasyarat maka dapat disimpulkan bahwa model struktural terpenuhi. Analisis selanjutnya adalah analisis Structural Equation Model (SEM) secara Full Model yang dimaksudkan untuk menguji model dan hipotesis yang dikembangkan dalam penelitian ini. Pengujian model dalam Structural Equation
Model dilakukan dengan dua pengujian, yaitu uji kesesuaian model dan uji signifikansi kausalitas melalui uji koefisien regresi. Hasil akhir pengolahan data terlihat pada gambar sebagai berikut:

Adapun model persamaan struktural berdasarkan hasil analisis adalah sebagai berikut:

Persamaan 1

$$
\begin{array}{ccc}
\text { Prososial }=0.54^{*} \text { Regulasi }+0.36 * \text { Dukungan, Errorvar. }=0.37, R^{2}=0.64 \\
(0.097) & (0.085) & (0.076) \\
5.51 & 4.26 & 4.91
\end{array}
$$

Persamaan 2

$$
\begin{array}{cc}
\text { Regulasi }= & 0.77^{\star} \text { Otoritat, Errorvar. }=0.37, \mathrm{R}^{2}=0.62 \\
(0.064) & (0.074) \\
11.93 & 4.92
\end{array}
$$

Setelah model tersebut memenuhi syarat, sama dengan uji t terhadap regression weight maka yang perlu dilakukan selanjutnya koefisien model. Adapun hasil pengujian adalah uji regression weight. Uji ini dilakukan sebagai berikut:

Tabel 5.Uji Hipotesis Penelitian

\begin{tabular}{lllcll}
\hline \multicolumn{2}{l}{ Pengaruh Antar Variabel } & & $\begin{array}{l}\text { Arah } \\
\text { Pengaruh }\end{array}$ & Nilai t & Keterangan \\
\hline Regulasi Emosi & $<---\begin{array}{l}\text { Pengasuhan Otoritatif } \\
\text { Orang Tua }\end{array}$ & + & 11.930 & $\begin{array}{l}\text { Hipotesis } \\
\text { Diterima } \\
\text { Hipotesis } \\
\text { Diterima } \\
\text { Hipotesis } \\
\text { Diterima }\end{array}$ \\
Perilaku Prososial & $<---\begin{array}{l}\text { Regulasi Emosi } \\
\text { Perilaku Prososial }\end{array}$ & $<---\begin{array}{l}\text { Dukungan Teman } \\
\text { Sebaya }\end{array}$ & + & 5.510 & + \\
\hline
\end{tabular}

Hasil analisis hipotesis di atas dapat dilihat bahwa berdasarkan dari Teori solimun (2011) tentang mediasi menjelaskan regulasi emosi mampu memediasi pengaruh pengasuhan otoritatif orang tua terhadap kecenderungan perilaku prososial di media sosial pada remaja secara tidak langsung.
Selanjutnya untuk mengetahui suatu mediasi penuh atau parsial, maka perlu diketahui tingkat signifikansi efek tidak langsung regulasi emosi sebagai variabel mediasi denan menghitung Sobel standar error (z-statistic) yang dikembangkan oleh Sobel (1982) sebagai berikut:

$Z=$ Pengasuhan Otoritatif Orang Tua $\rightarrow$ Regulasi Emosi $\rightarrow$ Perilaku Prososial

$$
\begin{aligned}
& z=\frac{a \times b}{\sqrt{\left(b^{2} \times S E_{a}^{2}\right)+\left(a^{2} \times S E_{b}^{2}\right)}} \\
& z=\frac{0,79 \times 0,52}{\sqrt{\left(0,52^{2} \times 0,64_{a}^{2}\right)+\left(0,79^{2} \times 0,85_{b}^{2}\right)}} \\
& z=0,54813882 \mid p \text {-value }=0,05
\end{aligned}
$$


Berdasarkan data diatas dapat diketahui bahwa $Z=0,55<1,96$ dengan $p$-value 0,05, maka dapat disimpulkan bahwa $(P)$ indirect effect $Z$ signifikan. Sehingga, dapat diketahui besarnya pengaruh langsung dan tidak langsung untuk menggambarkan kontribusi yang diberikan oleh masing-masing-masing variabel. Adapun hasil uji hipotesis dapat dilihat pada tabel sebagai berikut:

Selanjutnya untuk mengetahui besarnya pengaruh langsung dan tidak langsung untuk menggambarkan kontribusi yang diberikan oleh masing-masing-masing variabel. Adapun hasil dapat dilihat pada tabel sebagai berikut:

Tabel 6 Uji Hipotesis (Hubungan direct effect dan indirect effect antar variabel penelitian)

\begin{tabular}{lcc}
\hline \multicolumn{1}{c}{ Hipotesis } & \multicolumn{2}{c}{ Efek } \\
\cline { 2 - 3 } & Langsung & Tidak Langsung \\
\hline Pengasuhan Otoritatif $\rightarrow$ Regulasi Emosi & $0,79(79 \%)$ & - \\
Regulasi Emosi $\rightarrow$ Perilaku Prososial & $0,52(0,52 \%)$ & - \\
Pengasuhan Otoritatif $\rightarrow$ Regulasi Emosi $\rightarrow$ Perilaku & - & $0,42(42 \%)$ \\
Prososial & - & - \\
Dukungan Teman Sebaya $\rightarrow$ Perilaku Prososial & $0,36(36 \%)$ & - \\
\hline
\end{tabular}

Keterangan: $\mathrm{p}$-value $<0.05 ; \mathrm{N}=252$

Tabel 6 di atas menjelaskan besarnya kontribusi antar variabel baik secara tidak langsung maupun secara langsung.

\section{Pembahasan}

Perilaku prososial di media sosial merupakan fenomena terjadinya perilaku untuk saling menolong sesama dalam dunia internet. Hal tersebut perlu dijadikan referensi bagi dunia pendidikan karena perilaku prososial di media sosial dapat mendukung perkembangan sosial pada remaja.

Penelitian ini bertujuan untuk mengkaji pengasuhan otoritatif orang tua, dukungan teman sebaya dan regulasi emosi dengan kecenderungan perilaku prososial di media sosial oleh remaja, serta korelasi masingmasing kedua variabel sebagai eksogen dan satu variabel mediasi kecenderungan perilaku prososial di media sosial pada remaja. Diketahui dari hasil analisis yang telah dilakukan bahwa kedua variabel eksogen yakni pengasuhan otoritatif orang tua melalui regulasi emosi dan dukungan teman sebaya menunjukkan secara bersama-sama berhubungan positif terhadap kecenderungan perilaku prososial di media sosial pada remaja.

Perilaku prososial tidak hanya bisa dipengaruhi oleh salah satu faktor saja melainkan ada beberapa faktor. Eisenberg et al. (2006) berpendapat bahwa terbentuknya perilaku prososial tidak hanya dipengaruhi oleh faktor internal individu, melainkan juga dipengaruji faktor konteks. Faktor internal merupakan faktor yang berasal dari diri invividu baik biologi, emosi, afektif dan kognitif yang berkontribusi mempengaruhi prososial. Sedangkan faktor konteks merupakan pengaruh yang berasal dari luar individu seperti peran pengasuhan orang tua. Jauh sebelumnya Fabes et al. (1999) dan Carlo et al (1999) menjelaskan proses terbentuknya perilaku prososial yang dipengaruhi oleh faktor individu dan konteks, dimana faktor individu diantaranya gender, pubertas, prespective taking, moral reasoning, empati dan emosi yang terkait, proses kognitif, dan kepribadian. Faktor konteks keluarga, pengaruh teman sebaya, sekolah, dan budaya.

Peran gaya pengasuhan yang merupakan komponen penting dalam perkembangan emosi dan sosial termasuk mempengaruhi perkembangan regulasi emosi remaja, pengasuhan otoritatif yang merupakan kombinasi antara responsive dan demandingness memberikan dampak positif pada regulasi emosi anak dan remaja, sedangkan pengasuhan yang terlalu mengontrol berdampak pada kesulitan anak dan remaja dalam meregulasi emosi (Morris e al., 2017). 
Berdasarkan hasil penelitian Haque et al. (2013) remaja yang dibesarkan dalam pengasuhan otoritatif orang tua, mereka menunjukkan kemampuan mengatur emosi negatif dibandingkan dengan remaja yang dibesarkan dalam pengasuhan permisif dan otoriter. Ketika orang tua menerapkan pengasuhan otoritatif maka yang ada muncul emosi positif dalam bentuk kasih sayang, perhatian, dan mendukung anak. Emosi positif yang terus menerus ditunjukkan serta merta menyebabkan emosi positif pada anak, begitu juga sebaliknya ketika keluarga terus menerus menunjukkan emosi negatif menyebabkan emosi negatif yang melekat pada anak, sehingga membuat mereka mengalami kesulitan meregulasi emosi (Morris et al., 2007). Hal tersebut menjelaskan peran pengasuhan orang tua yang sangat krusial pada perkembangan sosial anak, sehingga sangat tidak mengherankan apabila dalam penelitian ini ditemukan kontribusi yang paling besar dimiliki oleh pengasuhan otoritatif orang tua sehingga hasil penelitian ini sangat sesuai menjelaskan peran pengasuhan orang tua terhadap perkembangan emosi remaja yakni regulasi emosi.

Berdasarkan hasil pengujian yang dilakukan dalam penelitian ini terhadap variabel pengasuhan otoritatif orang tua dan regulasi emosi menunjukkan bahwa pengasuhan otoritatif orang tua terbukti memiliki hubungan yang positif dan signifikan terhadap regulasi emosi yang ditunjukkan oleh nilai Construct Reliability terpenuhi dengan pengaruh langsung pengasuhan otoritatif orang tua terhadap regulasi emosi sebesar tujuh puluh sembilan persen. Hal ini menunjukkan bahwa semakin tinggi pengasuhan otoritatif orang tua yang dimiliki siswa di SMA Negeri 1 Surakarta dan SMA Negeri 5 Surakarta, maka semakin tinggi pula tingkat regulasi emosi yang ditunjukkan oleh remaja. Hubungan positif dalam penelitian ini mendukung hasil penemuan penelitian sebelumnya yang dilakukan oleh Carlo, dkk (2012) dan Padilla-Walker \& Chirstensen (2011) yang menunjukkan bahwa ada hubungan positif antara pengasuhan ototitatif orang tua dengan regulasi emosi. Hal tersebut menjelaskan peran pengasuhan orang tua yang sangat krusial pada perkembangan emosi anak, sehingga sangat tidak mengherankan apabila dalam penelitian ini ditemukan kontribusi yang paling besar dimiliki oleh pengasuhan otoritatif orang tua sehingga hasil penelitian ini sangat sesuai menjelaskan peran pengasuhan orang tua terhadap perkembangan emosi remaja yang mempengaruhi perilaku prososialnya.

Hubungan regulasi emosi dan perilaku prososial di media sosial. Hasil pengujian yang dilakukan dalam penelitian ini terhadap variabel regulasi emosi dan perilaku prososial di media sosial menunjukkan bahwa regulasi emosi memiliki hubungan yang signifikan terhadap perilaku prososial di media sosial yang ditunjukkan oleh nilai Construct Reliability terpenuhi dengan efek langsung (direct effect) sebesar lima puluh dua persen. Hal ini menunjukkan bahwa semakin tinggi regulasi emosi yang dimiliki oleh siswa SMA Negeri Surakarta, semakin tinggi pula perilaku prososial di media sosial remaja. Artinya bahwa semakin tinggi regulasi emosi, maka semakin tinggi pula tingkat perilaku prososial di media sosial remaja.

Hubungan tersebut disebabkan perkembangan perilaku prososial tidak lepas dari peran emosi dan regulasi emosi merupakan kemampuan mengendalikan dan mengatur emosi negatif dan positif saat dihadapkan dengan kondisi yang menantang, kondisi yang tidak menyenangkan, dan saat berhubungan dengan orang lain yang bisa mempengaruhi emosi mereka. Seperti yang dijelaskan oleh Eisenberg et al. (2006) perilaku prososial dan regulasi emosi saling berkaitan sebab perilaku prososial membutuhkan pengaturan dan control emosi negatif untuk meningkatkan emosi positif.

Artinya ketika dihadapkan dengan media sosial partisipan penelitian mampu mengendalikan dan mengontrol emosi negatif dengan baik, yakni dengan mengubah cara berpikir negatif dan menghambat ekspresi emosi negatif yang mempengaruhi perilaku. Peran regulasi emosi terhadap kecenderungan perilaku prososial, sama dengan hasil penelitian Kanacri et al. (2012) kemampuan remaja untuk menghambat 
respon emosi negatif yang dominan mampu mempengaruhi tingginya kecenderungan perilaku prososial mereka, baik pada remaja laki-laki dan perempuan. Dalam penelitian ini menjelaskan untuk memunculkan emosi positif yang mampu menggerakkan remaja menjadi lebih peka dan peduli terhadap orang lain membutuhkan kemampuan regulasi emosi yang baik, sehingga mereka mampu mengatasi reaksi emosi negatif yang muncul.

Benita et al. (2016) temuannya menjelaskan hasil penelitiannya bahwa secara langsung regulasi emosi integratif mampu mempengaruhi perilaku prososial, hal tersebut juga sejalan dengan penelitian Hein et al. (2016) menemukan hal yang sama bahwa individu yang memiliki kemampuan dalam meregulasi emosi berhubungan dengan tingginya empati dan perilaku prososial. Hal tersebut menjelaskan remaja yang memiliki kemampuan meregulasi emosi yakni mengatur emosi negatif seperti rasa sedih, marah, kecewa, tertekan, dan terlalu membanggakan diri sendiri, mampu memfasilitasi emosi positif yang pada akhirnya mempengaruhi perilaku prososial secara langsung maupun sebagai mediator perilaku prososial di media sosial.

Sama halnya dengan perilaku prososial secara langsung, perilaku prososial melalui media sosial juga melibatkan emosi. Erreygers et al. (2017) menjelaskan emosi seringkali mempengaruhi munculnya perilaku sosial di media sosial. Ketika seseorang lebih mampu mengelola emosi positif, mereka lebih terlibat dengan interaksi sehat dengan melakukan hal-hal yang bermanfaat untuk orang lain melalui media sosial seperti memberikan bantuan kepada orang yang membutuhkan pertolongan dan menjaga hubungan baik dengan teman.

Temuan bahwa regulasi emosi berperan positif terhadap perilaku prososial sebagai variabel mediasi sependapat dengan penelitian yang dilakukan oleh Lockwood et al. (2014), bahwa regulasi emosi reappraisal secara langsung tidak berhubungan signifikan dengan perilaku prososial dan regulasi emosi suppression berhubungan negative dengan prososial, tetapi regulasi emosi reappraisal secara positif menjadi moderator antara empati dan kecenderungan prososial.

Hasil penelitian ini menjelaskan bagaimana regulasi emosi memainkan peran yang penting selama perkembangan masa remaja, yang mana remaja sering digambarkan dengan kondisi emosi yang ekstrim dan tidak menentu. Sesuai dengan yang disebutkan oleh Hall (dalam Santrock, 2011) remaja dikarakteristikan dengan masa emosi yang bergejolak, mereka juga sering mengungkapkan emosi yang tidak menyenangkan pada orang-orang terdekat atau yang dikenal dengan meledak-ledak tanpa perlu di provokasi (Santrock, 2011), sehingga adanya regulasi emosi sangat tepat membantu remaja mengendalikan dan mengatur emosi negatif yang berasal dari pengalaman yang tidak menyenangkan atau menantang. Melalui kemampuan meregulasi emosi remaja lebih bisa membuat keputusan yang tepat dan lebih siap mengelola dorongan negatif yang pada akhirnya mempengaruhi perkembangan positif yakni perilaku prososial (Buckley \& Saarni, 2009).

Peran regulasi emosi sebagai faktor internal tidak bisa berdiri begitu saja mempengaruhi kecenderungan perilaku prososial pada remaja, sebab perilaku prososial sebagai perilaku sosial selalu bersinggungan dengan lingkungan disekitarnya sehingga tidak bisa dipungkiri faktor eksternal memberi pengaruh juga. Hal tersebut telah dijelaskan oleh Bronfrenbenner (1977) perkembangan anak dipengaruhi oleh interaksi internalnya dengan lingkungan disekitarnya seperti dukungan teman sebaya. Dengan demikian dapat dipertegas bahwa perilaku sosial remaja ada sebaba banyak faktor yang mempengaruhi.

Hubungan dukungan teman sebaya dan perilaku prososial di media sosial. Hasil pengujian yang dilakukan dalam penelitian ini terhadap variabel dukungan teman sebaya dan perilaku prososial di media sosial menunjukkan bahwa dukungan teman sebaya memiliki hubungan yang positif dan signifikan terhadap perilaku prososial di media sosial yang ditunjukkan oleh nilai Construct Reliability terpenuhi dengan efek 
langsung (direct effect) sebesar tiga puluh enam persen. Hal tersebut membuktikan bahwa terdapat dukungan teman sebaya meningkakan perilaku prososial dimedia sosial pada remaja. Hal ini mendukung hasil penemuan penelitian sebelumnya yang dilakukan Salomon (2004) bahwa dukungan teman sebaya juga mempengaruhi perilaku prosisal indvidu, dimana semakin tinggi dukungan teman sebaya maka semakin tinggi juga perilaku prososial remaja. Demikian pula yang dikemukakan oleh Smet (1994) bahwa dukungan sosial mengacu pada kesenangan yang dirasakan, penghargaan akan kepedulian dan membantu orang menerima dari orang-orang atau kelompok-kelompok lain. Dengan demikian, hasil penelitian ini juga memperkuat pendapat Fabes, Carlo, Kupanoff, dan Lailable (1999) yang mengemukakan bahwa proses konteks sosial yang mampu mempengaruhi perkembangan perilaku prososial salah satunya yaitu pengaruh teman sebaya.

Berdasarkan pengujian (z-statistic) menunjukkan adanya efek tidak langsung antara variabel-variabel yang diteliti, karena nilai zobel terpenuhi, maka dapat disimpulkan bahwa indirect effect signifikan. Artinya bahwa, variabel regulasi emosi merupakan variabel mediator dengan kata lain pengasuhan otoritatif orang tua tidak serta merta berkorelasi langsung terhadap perilaku prososial di media sosial melainkan melalui regulasi emosi sebagai variabel mediator. Dengan demikian, hasil penelitian ini juga membuktikan hipotesis bahwa terdapat hubungan antara pengasuhan otoritatif orang tua dengan perilaku prososial di media sosial melalui variabel mediasi regulasi emosi pada remaja.

Orang tua yang menanamkan dasar perilaku prososial sejak dini. Sebelum anak belajar tentang moral yang diterima di sekolah, jauh sebelumnya orang tua mengajarkan anak mereka tentang perilaku yang bisa diterima dan tidak diterima oleh keluarga dan masyarakat, yang kemungkinan melekat hingga remaja. Selain itu besar kemungkinan anak menjadikan orang tua sebagai role model. Figur orang tua yang positif melekat pada penilaian remaja untuk dijadikan role model dalam bersikap, sesuai dengan teori belajar sosial yang menekankan bahwa suatu perilaku dapat terbentuk dari proses belajar seorang anak melalui pengamatan dan penguatan oleh model sosial seperti orang tua (Shaffer, 2009).

Hasil penelitian ini mendukung penelitian Rochmah (2018) yang menyatakan bahwa pengasuhan otoritatif orang tua berpengaruh terhadap perilaku prososial di media sosial dan regulasi emosi berpengaruh terhadap perilaku prososial di media sosial. Hal ini didukung juga dengan penelitian sebelumnya yang dilakukan oleh Padilla-Walker et al. (2012), pengasuhan otoritatif seperti memberi dukungan dan mengizinkan kemandirian (autonomy granting) yang diterapkan orang tua pada remaja menunjukkan mereka lebih sering dalam hasil disertasinya bahwa pengasuhan otoritatif merupakan prediktor yang memilih pengaruh tinggi terhadap perilaku prososial remaja. Senada dengan yang dikemukakan Carlo et al. (2012) dan Padilla-Walker \& Chirstensen (2011) bahwa pengasuhan otoritatif orang tua memiliki hubungan yang positif dengan perilaku prososial remaja

Penelitian ini juga memperlihatkan demografi partisipan yang didominasi perempuan dibandingkan dengan remaja lakilaki dengan usia empat belas sampai enam belas tahun sebanyak enam puluh delapan persen dan sisanya usia tujuh belas sampai sembilan belas tahun sebanyak tiga puluh dua persen. Hal tersebut mungkin disebabkan oleh emosi positif yang lebih melekat pada remaja perempuan seperti empati, mereka lebih memiliki ketertarikan untuk mendukung kegiatan relawan yang tersedia di media sosial daripada laki-laki (Paulin et al. 2014). Kecenderungan prososial dilihat dari jenis kelamin juga disebutkan Carlo et al. (2011) bahwa perempuan lebih empati sehingga lebih memiliki kesadaran untuk peduli dengan kondisi kesulitan yang dialami orang lain, mereka juga mampu memahami apa yang dirasakan orang lain sehingga dengan ringan bersedia memberikan pertolongan dan bantuan. 
Lama waktu yang digunakan dalam menggunakan media sosial juga diperhatikan, diketahui bahwa lama waktu yang dihabiskan remaja untuk menggunakan media sosial Instagram, Whatsapp, Youtube, Line, dan Tik Tok menunjukkan hubungan yang signifikan terhadap perilaku prososial. Adanya hubungan positif diantara keduanya kemungkinan disebabkan interaksi positif yang dilakukan selama menggunakan media sosial, berupa melakukan hal-hal yang baik dengan lebih peduli dan perhatian dengan kondisi orang lain, memberi dukungan emosional, lebih senang berbagi informasi dan pengetahuan, serta mau mengambil resiko menolong teman yang mengalami kekerasan yang terjadi di media sosial. Sehingga lama waktu menggunakan media sosial jika dimanfaatkan untuk berinteraksi secara sehat, maka memberikan pengalaman positif pada remaja yang mengarahkan mereka semakin berperilaku prososial di media sosial (Legate, 2016). Wright \& LI (2011) terlebih dahulu menegaskan dalam hasil penelitiannya, semakin lama seseorang menggunakan media sosial semakin terlibat dalam kecenderungan perilaku prososial di media sosial tersebut.

Dapat disimpulkan dari hasil temuan penelitian ini terdapat beberapa kelemahan yaitu penentuan sampel populasi hanya pada kecamatan Banjarsari, mengingat populasi remaja di Kota Surakarta tidak hanya pada kecamatan Banjarsari saja melainkan terdiri dari kecamatan Laweyan, Jebres, Pasar kliwon, dan Serengan. Kedua, indikator dari konstruk pada skala penelitian antara dua hingga empat indikator saja, sehingga ketika diuji model CFA cenderung hasil olah data kurang optimal. Ketiga,standar kriteria yang diterapkan pada partisipan yang menjadi sampel kurang sesuai dengan partisipan yang diambil, sehingga beberapa kuesioner tidak dapat digunakan karena partisipan tidak memenuhi kriteria yang dibutuhkan dalam penelitian. Dan keempat, setiap variabel dalam penelitian ini menggunakan nilai goodness of fit melalui tahapan modification indicies, sehingga terdapat banyak pola korelasi dari indikator hasil pengujian.

\section{Kesimpulan}

Berdasarkan hasil analisis dan pembahasan penelitian dapat disimpulkan bahwa pengasuhan otoritatif orang tua melalui regulasi emosi dan dukungan teman sebaya memiliki peran sebagai prediktor kecenderungan perilaku prososial di media sosial pada remaja. Pengasuhan otoritatif orang tua sebagai faktor internal berhubungan positif terhadap kecenderungan perilaku prososial di media sosial yang dimediasi oleh regulasi emosi, begitu pula dengan dukungan teman sebaya yang merupakan faktor konteks memiliki peran kontribusi yang lebih besar dari pengasuhan otoritatif orang tua mempengaruhi perilaku prososial.

\section{Daftar Pustaka}

Afrianti, N., \& Anggraeni, D. (2016). Perilaku Prososial Remaja Dalam Perspektif Bimbingan Konseling Islami. Jurnal Pendidikan Islam, 5(1), 1-114

Altay, F. B \& Gürea, A. (2012). Relationship among the parentng style and the social competence and prosocial behaviors of the children who are attending to state and private preschools. Educational Sciences: Theory and Practice, 12(4), 2712-2718.

Azwar, S. (2014). Metode penelitian. Yogyakarta: Pustaka Belajar.

Bandura, A. (1977). Social Learning Theory. New Jersey: Prentice-Hall, Inc.

Benita, M, Lehkovitz, T., \& Roth, G. (2016). Integrative emotion regulation predicts adolescent's prosocial behavior the mediation of empathy. Learning and Instruction, 50, 14-20.

Bosancianu, C.M, Powell, S., \& Bratovic, E. (2013). Social capital and pro-social behavior media sosial and offline. International journal of internet science, 8, 49-68.

Carlo, G., Crockett, L. J., Wolff, J. M., \& Beal, S. J. (2012). The role of emotional reactivity, self-regulation, and puberty in adolescents' Prosocial Behavior. Temperament and Prosocial Behavior, 
21(4), 667-685.

Carlo, G., Mestre, M.V., McGinley, M.M., Porcar, A.T., Samper, P., \& Opal, D. (2014). The protective role of prosocial behaviors on antisocial behaviors: the mediating effects of deviant peer affiliation. Journal of Adolescence, 37, 359- 366.

De Caroli, M.E., \& Sagone ${ }^{a}$, E. (2014). Belief in a just world, prosocial behavior, and moral disengangement in adolescence. Social and Behavioral Sciences, 116, 596-600.

Dowell, Mina, K, Robin O'Neil, \& Ross, D. (2002). Children's Emotional Regulation and Social Competence in Middle Childhood. Marriage \& Family Review, 34(3), 345-364.

Eisenberg, N., Fabes, R.A., \& Spinrad, T.L. (2006). Prosocial behavior. In N. Eisenberg, W. Damon, \& R.M Lerner (Eds.), Handbook of Child Psychology: Social, Emotional, and Personality Development Sixth Edition (pp. 647-702). New Jersey: John Wiley and Sons Ins.

Eisenberg, N., Hofer, C., Sulik, M. j., \& Spinrad, T. L. (2014). Self-regulation, Effortful Control, and Their Socioemotional Coreelates. In James J. Gross (Eds.), Handbook of Emotion Regulation Second Edition (pp.157-172). New York: The Guilford Press.

Erreygers, S., Vandebosch, H., Vranjes, I., Baillin, E, \& De, H. (2017). Nice or naughty? The role of emotions and digital media use in explaining Adolescents media sosial prosocial and antisocial behavior. Media psychology, 20(3), 374400.

Fabes, R.A., Carlo, G., Kupanoff, K., \& Lailable, D. (1999) early adolescence and prosocial/moral behavior I: the role of individual processes. Journal of Early Adolescence. 19(1), 5-16.

Ferdinand, Augusty. (2000). Structural Equation Modelling dalam Penelitian. Semarang: Penerbit Universitas Diponegoro.

Ferenczi, N., Marshall, T.C., Bejanyan, K. (2017). Are sex differences in antisocial and prosocial facbook use explained by narcissi, and relational self-construal. Computer in Human Behavior, 77, 25-31.

Gagné, M. (2003). The role of autonomy support and autonomy orientation in prosocial behavior engagement. Motivation and Emotion, 27(3), 199-223.

Gross, J. J. (2014). Emotion regulation: Conceptual and empirical foundation. In James J. Gross (Eds) Handbook of Emotion Regulation Second Edition (pp. 3-22). New York: The Guilford Press.

Hair, J. F., Black. W. C., Babin. B. J., \& Anderson. R. E. (2010). Multivariate Data Analysis, $7^{\text {th }}$ ed. New Jersey: Pearson Prentice Hall.

Haque, M. A. U., \& Riaz, M. N. (2013). Parenting styles as predictors of emotion regulation among adolescents. Pakistan Journal of Psychological Research, 28(1), 85-105.

Hein, S., Roder, M, \& Fingerle, M. (2016). The role of emotion in situational empathyrelated responding and prosocial behavior in the presence of negative affect. International Journal of Psychology. DOI:10.1002/ijop.12405.

Johnson, M \& Krettenauer, T. (2011). Moral self and moral emotion expectancies as predictors of anti-and prosocial behavior in adolescence: A case for mediation? European Journal of Developmentak Psychology, 8(2), 228-243.

Legate, A. N. (2017). Social, emotional, cognitive, and psychological correlates of electronic social behavior (Master Tesis). University Kingston, Canada. http://qspace. library.quuensu.ca/handle/1974/14838.

Lockwood, P.L., Seara-Cardoso, A., \& Viding, E. (2014). Emotion regulation moderates the association between empathy and prosocial behavior. PLoS ONE, 9(5), 1-7.

Luthfie, Nukman. (2011, Agustus 05). Mengapa me-Retweet? Retrieved from http://www.virtual.co.id.

Kahana, E., Bhatta, T., Lovergreen, L. D., Kahana, B., \& Midlarsky, E. (2013). Altruism, helping, and volunteering: Pathways to well-being in late life. Journal of Aging and Health, 25(1), 159-187.

Kanacri, B. P. L., Pastorelli, C., Eisenberg, 
N., Zuffianò, A, \& Caprara, G. V. (2012). The development of prosociality from adolescence to early adulthood: the role of effortful control. Journal of Personality, 81(3), 302-312.

Morris, A. S., Silk, J. S., Steinberg, L., Myers, S. S., \& Robinson, L. R. (2009). The role of the family context in the development of emotion regulation. Social Development, 16, 361-388.

Otterpohl, N \& Wild, E. (2015). Cross-lagged relations among parenting, children's emotion regulation, and psychosocial adjustment in early adolescence. Journal of Clinical Child \& Adolescent Psychology, 44(1) 93-108.

Padilla-Walker, L. M., Carlo, G., Christensen, K. J., \& Yorganson, J. B. (2012). Bidirectional relations between authoritative parenting and adoelscents' prosocial behavior. Journal of Research on Adolescence, 22(3), 400-408.

Padilla-Walker, L.M., \& Christensen, K.J. (2011). Empathy and self-regulation as mediators between parenting and adolescents' prosocial behavior toward strangers, friends, and family. Journal of Research on Adolescence, 21(3), 545551.

Rochmah, K. U. (2018). Peran regulasi emosi dan pengasuhan otoritatif ibu terhadap kecenderungan perilaku prososial di media sosial pada remaja. Yogyakarta: Universitas Gadjah Mada.

Salomon, P. (2004). Peer Support/Peer Provide Service Underlying Processes, Benefits, And Critical Ingredients. Psychiatric Rehabilitation Journal, 27(4), 392-401.

Smet, B. (1994). Psikologi Kesehatan. Jakarta: PT. Gramedia Widiasarana Indonesia.

Santrock, J. W. (2014). Adolescence Fifteenth Edition. New York: McGraw-Hill.

Solimun. (2011). Analisis Variabel Moderasi dan Mediasi. Malang: Program Studi Statistika FMIPA Universitas Brawijaya.

Steinberg, L. (2011). Adolescents ninth edition. New York. McGRar-Hill International Edition.

Sugiyono. (2014). Memahami Penelitian
Kualitatif. Bandung: Alfabeta.

Waldinger, R., \& Schulz, M. S. (2016). The Long Reach of Nurturing Family Environments: Links With Midlife Emotion-Regulation Styles and Late-Life Security in Intimate Relationships. Psychological Science. DOI:10.1177/0956797616661556.

Wright, M.F., \& Li, Y. (2011). The associations between young adults face to face prosocial behaviors and theur media sosial prosocial behaviors. Computer in Human Behavior. 27, 1959-1962.

Yoo, H., Feng, X., \& Day, R.D. (2013). Adolescent empathy and prosocial behavior in the family context: A Longiudinal study. Journal Youth Adolescence, 42, 1858- 1872. 